\title{
GROWTH AND EARLY REPRODUCTION DEVELOPMENT OF THE FIRST GENERATION OF SHEATFISH, Ompok miostoma (Vaillant, 1902) REARED IN CONTROLLED CONCRETE TANKS
}

\author{
Rudhy Gustiano, Vitas Atmadi Prakoso\#, Kurniawan Kurniawan, and Wahyulia Cahyanti \\ Research Institute for Freshwater Aquaculture and Fisheries Extension \\ Jl. Sempur No. 1, Bogor 16129
}

(Received: March 9, 2021; Final revision: April 30, 2021; Accepted: May 7, 2021)

\begin{abstract}
This study was conducted to observe the growth and reproductive biology of wild sheatfish in controlled concrete tanks. The research was carried out from January to November 2020 at the Research Station for Freshwater Fisheries Germplasm, Cijeruk, Bogor. Sampled fish were captured from Cilala Lake in Bogor and Cipanas River in Sumedang, West Java. The collected fish were $14.6 \pm 2.24 \mathrm{~cm}$ in length and $21.5 \pm 9.19$ $\mathrm{g}$ in weight. Growth and reproductive biology parameters were measured every 30 days. Cortisol, estradiol, vitellogenin, testosterone, glucose, and hemoglobin were also determined as the supporting parameters for gonadal maturity. Measured water quality parameters were temperature, $\mathrm{pH}$, dissolved oxygen, ammonia, and alkalinity. The results showed that sheatfish grew with a specific growth rate of $0.4 \pm 0.15 \%$ day, FCR of $3.2 \pm 0.26$, and survival rate of $100 \%$ Observation on the gonad maturity found that the fish studied were in the level-I and II. There are no significant differences regarding the supporting parameters $(P>0.05)$ on the fish examined, despite the tendency of decreasing cortisol, and increasing testosterone. Based on the results, this study concludes that the observed fish can adapt, grow, and start to mature their gonads in their new environment, with temperature as one of the possible key factors influencing its gonad development.
\end{abstract}

\section{KEYWORDS: sheatfish; reproductive biology; growth; physiology; domestication}

\section{INTRODUCTION}

Many popular freshwater catfish species belong to genera Ompok and Kryptopterus of sheatfish or "lais/ silais". Both genera are considered an economically important catfish group to supply protein demand in the form of fresh fish or processed ones, e.g., smoked and salted fish. For example, certain provinces in Indonesia have placed the fish group as one of the valuable and most sought-after fish commodities (Sukadi et al., 2009; Muslim et al., 2020). Nowadays, the production of sheatfishes in several main producer areas has gradually decreased year by year due to several reasons such as over exploitation, degraded natural habitat and other anthropogenic pressures. Therefore, efforts are needed to conserve the fish wild stock and ensure its future sustainable production via fish breeding and domestication programs. However, there is limited biological information regarding the sheatfish reproduction, a basic knowledge needed for domestication. The lack of definitive in-

\footnotetext{
* Correspondence: Research Institute for Freshwater Aquaculture and Fisheries Extension. Jl. Sempur No. 1, Bogor 16129 E-mail: vitas.atmadi@gmail.com
}

formation on the biological aspects of this fish group in its natural habitats has hindered the planning and implementation of the species conservation and management strategies (Jusmaldi et al., 2017).

To be classified as a domesticated species, the fish's life cycle must be completely closed in captivity and independent of their wild habitat. Teletchea $\&$ Fontaine (2014) suggested six criteria of domestication level for fish in aquaculture: "capture fisheries (level-0), first trials of acclimatization to the culture environment (level-1), part of the life cycle is completed in captivity, but several important bottlenecks still exist in others (level-2), the entire life cycle is closed in captivity, but with wild inputs (level-3), the entire life cycle is closed in captivity without wild inputs, but no selective breeding program is used (level-4), and selective breeding program is used focusing on specific goals (growth rate, fillet yield, flesh quality, etc) (level-5)" (p.7). Balon (2004) stated that domesticated species have different breeding characteristics compared to their ancestor, because humans have altered them to suit with the new environment or habitats. 
The reproduction of Ompok has been reported since the last decade in Indonesia (Sjafei et al., 2008; Handayani et al., 2009; Elvyra et al., 2010; Minggawati et al., 2015; Jusmaldi et al., 2017). In India, the reproduction and breeding of 0 . bimaculatus have been published by Arthi et al. (2013) and Malla \& Banik (2015). However, studies concerning the domestication, reproductive biology, and growth of 0 . miostoma in Indonesia have not been explored yet. This research was conducted to observe the growth and reproductive biology of wild-caught sheatfish 0 . miostoma in a controlled environment.

\section{MATERIALS AND METHODS}

The study was carried out from January to November 2020 at the Research Station for Freshwater Fisheries Germplasm, Cijeruk, Bogor. Fish were captured from Cilala Lake, Bogor $\left(6^{\circ} 28^{\prime} \mathrm{S}\right.$ and $106^{\circ} 42^{\prime}-$ $106^{\circ} 43^{\prime} \mathrm{E}$; water temperature range: $29^{\circ} \mathrm{C}-33.8^{\circ} \mathrm{C}$ (Pratiwi et al., 2007; Wisnu et al., 2021)) and Cipanas River, Sumedang $\left(6^{\circ} 67^{\prime} 70^{\prime \prime} S\right.$ and $108^{\circ} 02^{\prime} 58^{\prime \prime} \mathrm{E}$; water temperature range: $26^{\circ} \mathrm{C}-30^{\circ} \mathrm{C}$ (Herawati et al., 2020a; Herawati et al., 2020b)), West Java. After transportation processes, fish were acclimated and adapted in indoor aerated and thermoregulated concrete tanks sized $170 \mathrm{~cm} \times 120 \mathrm{~cm} \times 100 \mathrm{~cm}$ with $40 \mathrm{~cm}$ water level. During adaptation, the fish were fed with live feeds (Tubifex) and then replaced by a commercial feed (30\% protein), which was given every morning and evening. The adaptation process was carried out until August 2020. After that, all fish were kept in four tanks with a stocking density of 7 fish/tank. The same commercial feed was given ad libitum until the end of the experiment for 60 days. In order to maintain the optimal water tank quality for sheatfish, partial water exchange was done every two weeks, and primary water quality parameters were measured regularly.

For the growth performance test, the fish used had length and weight of $14.6 \pm 2.24 \mathrm{~cm}$ and $21.5 \pm$ $9.19 \mathrm{~g}$, respectively. Growth concerning length gain, weight gain, specific growth rate, and survival rate, and reproductive biology parameters such as gonad maturity level, fecundity, gonad weight, and gonadosomatic index (GSI) were observed every 30 days. Cortisol, estradiol, vitellogenin, testosterone, glucose, and hemoglobin were also determined as the supporting parameters for gonadal maturity. Fish weight was measured using a digital scale with an accuracy of $0.01 \mathrm{~g}$, while the length was measured to an accuracy of $0.1 \mathrm{~cm}$ using a laminated graph paper. The parameters observed were length gain, weight gain, biomass gain, specific growth rate (SGR), feed conversion ratio (FCR), and survival rate (SR). The survival rate was calculated at the end of the experi- ment. The reproductive biology was observed by dissecting the fish collected from the same location as the tested fish $(n=3)$. The observed reproductive parameters included fecundity, gonad weight, GSI, gonad histology, and gonad maturity level. Gonad's weight was weighed using a digital scale. Fecundity was calculated using the equation proposed by Bagenal (1978). Gonad histology preparation was carried out following the method suggested by Wolf \& Smith (1999). GSI was calculated using the formula proposed by Effendie (1997). Meanwhile, gonad maturity level was determined by following Longenecker et al. (2020).

The physiological response was observed by collecting blood samples from an individual fish $(n=$ 3 for each male and female) at the beginning, middle, and end of the study to observe glucose, hemoglobin, estradiol, cortisol, testosterone, and vitellogenin. Prior to blood sample collection, the fish were anesthetized with 2-phenoxyethanol at a dose of $1 \mathrm{~mL} / \mathrm{L}$. Blood $(0.5 \mathrm{~mL})$ was collected from the caudal vein using a $1 \mathrm{~mL}$ heparinized syringe. For glucose measurement, one drop of each collected blood sample was applied to a blood glucose reader (ACCU-CHEK Active, Roche, Germany). Meanwhile, $0.1 \mathrm{~mL}$ of each blood sample was used to measure hemoglobin using a haemometer (Marienfeld Superior, Germany) according to the Sahli's method (Sahli, 1909). The remaining blood samples were extracted using a centrifuge machine (Heraeus Biofuge Pico) with a speed of $10,000 \mathrm{rpm}$ for five minutes to collect the plasma.

Furthermore, the blood plasma from each sample was analyzed for cortisol, estradiol, testosterone, and vitellogenin levels using ELISA kits (DRG International, Germany for Cortisol, Estradiol, and Testosterone; Bioenzy for Vitellogenin) and microplate photometer (Biosan HiPo MPP-96, Latvia). Measurements were made at the beginning, middle, and end of the experiment. For statistical analysis, ANOVA tests were performed on each physiological parameter to compare the values observed at the beginning, middle, and end of the experiment. The data obtained were analyzed using the R software (R Core Team, 2020). As complementary data, water quality parameters were measured in this study, including temperature, $\mathrm{pH}$, dissolved oxygen, ammonia, and alkalinity. Temperature, $\mathrm{pH}$, and dissolved oxygen were monitored every day (morning and evening), while ammonia and alkalinity were measured every week.

\section{RESULTS AND DISCUSSION}

The results showed that fish grew and developed in the concrete tanks during 60 days of observation (Table 1). 
Table 1. Growth of sheatfish, 0 . miostoma during 60 days of rearing in concrete tanks

\begin{tabular}{lccc}
\hline \multicolumn{1}{c}{ Parameters } & Initial & Final & Gain/Value \\
\hline Length $(\mathrm{cm})$ & $14.6 \pm 2.24$ & $16.4 \pm 1.85$ & $1.7 \pm 0.82$ \\
Weight $(\mathrm{g})$ & $21.5 \pm 9.19$ & $26.9 \pm 10.65$ & $5.4 \pm 2.61$ \\
Biomass $(\mathrm{g})$ & $150.3 \pm 3.89$ & $188.2 \pm 1.82$ & $38.0 \pm 5.71$ \\
Specific growth rate (\%)day) & & & $0.4 \pm 0.15$ \\
Feed conversion ratio & & & $3.2 \pm 0.26$ \\
Survival rate (\%) & & & $100.0 \pm 0.00$ \\
\hline
\end{tabular}

Observations on the reproductive biology of 0 . miostoma related to fecundity, gonad weight, GSI, and gonad maturity levels are presented in Table 2. Meanwhile, gonad histological observations are shown in Figure 1.
Based on Figures $1 \mathrm{~A} \& 1 \mathrm{~B}$, oocytes are categorized as stage-I because the oocytes were angular or irregularly shaped with a circular nucleus. Moreover, most cytoplasm in these figures stain darkly and is uniformly similar to those observed by Longenecker

Table 2. Fecundity, gonad weight, GSI, and gonad maturity level of sheatfish 0. miostoma from the smallest and the biggest of ten specimens

\begin{tabular}{ccccccc}
\hline Sample & $\begin{array}{c}\text { Length } \\
(\mathbf{c m})\end{array}$ & $\begin{array}{c}\text { Weight } \\
\mathbf{( g )}\end{array}$ & $\begin{array}{c}\text { Fecundity } \\
\text { (eggs) }\end{array}$ & $\begin{array}{c}\text { Gonad weight } \\
\mathbf{( g )}\end{array}$ & GSI & $\begin{array}{c}\text { Gonad } \\
\text { maturity }\end{array}$ \\
\hline 1 & 15.6 & 29.59 & 1,160 & 0.04 & 0 & 1 \\
2 & 19.1 & 47.71 & 11,424 & 1.7 & 3.3 & II \\
\hline
\end{tabular}
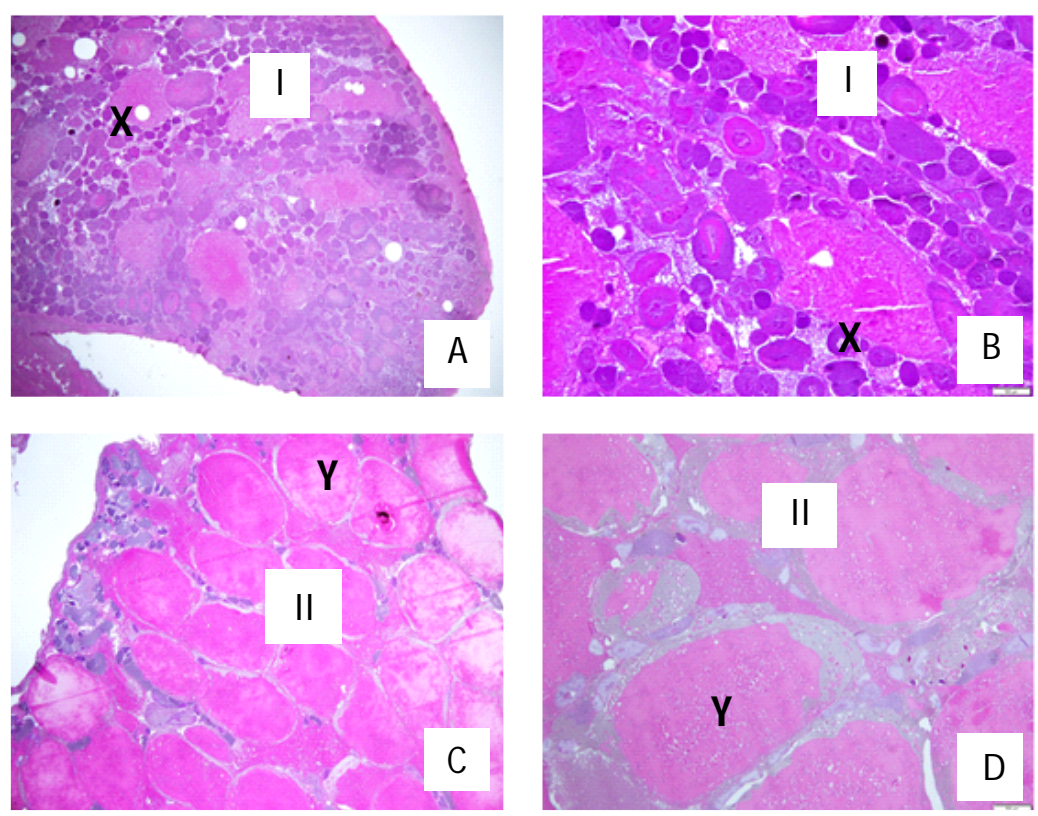

$4 \times$ magnification

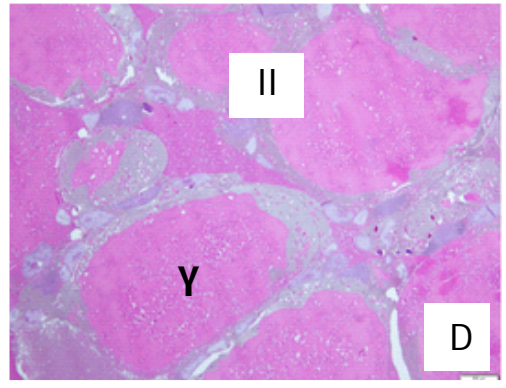

$10 \times$ magnification

Figure 1. Gonad histology of sheatfish 0 . miostoma using hematoxin-eosin (A and B showed fish sample number-1 with $14.5 \mathrm{~cm}$ SL and $34.5 \mathrm{~g} \mathrm{BW}$; C and D showed fish sample number-2 with $15.5 \mathrm{~cm} \mathrm{SL}$ and $51.7 \mathrm{~g} \mathrm{BW}$; numbers are indicating gonad maturity level; X: perinuclolar oocytes; Y: cortical alveoli oocytes). 
et al. (2020). Figures 1C \& 1D show a smoother and larger shape of oocytes with an indistinct boundary between the nucleus and cytoplasm. This shape indicates the sign of stage-II. In addition, lipid vesicles at stage-II appeared at the periphery of the cell (Longenecker et al., 2020).

The physiological observations for 60 days are presented in Figure 2. All observed parameters were not significantly different $(P>0.05)$. Cortisol levels tended to decrease from $282.0 \pm 124.42 \mathrm{ng} / \mathrm{mL}$ initially to $158.9 \pm 54.81 \mathrm{ng} / \mathrm{mL}$ at the final observation. Estradiol ranged from $137.7-209.7 \mathrm{pg} / \mathrm{mL}$ and vitellogenin ranged from $62.4-79.2 \mu \mathrm{g} / \mathrm{mL}$. No significant differences were found on estradiol and vitellogenin at the initial observation compared to the final observation. Testosterone levels showed a positive trend of increasing from $2.0 \pm 0.81 \mathrm{ng} / \mathrm{mL}$ initially to $4.1 \pm 3.39 \mathrm{ng} / \mathrm{mL}$ at the end of observa- tion, but the changes were not significant. Fluctuating patterns were also found in glucose and hemoglobin, ranging between $45.5-85.5 \mathrm{mg} / \mathrm{dL}$ and $6.6-6.4$ $\mathrm{g} / \mathrm{dL}$, respectively.

During the study, the water temperature in the tanks ranged from $29.4^{\circ} \mathrm{C}$ to $31.1^{\circ} \mathrm{C}$, dissolved oxygen from 5.3 to $7.2 \mathrm{mg} / \mathrm{L}$, pH from 6.6 to 7.8 , alkalinity from 50 to $76 \mathrm{mg} / \mathrm{L}$, and ammonia levels less than $0.001 \mathrm{mg} / \mathrm{L}$ (Table 3).

According to Boyd (2000), the water quality measured was still in the optimal range for fish. Furthermore, in terms of gonad maturation, previous studies reported that salinity, temperature, and dissolved oxygen are the abiotic factors likely to impact the fecundity and egg size (De Silva, 1986; Legendre \& Ecoutin, 1989). Among water quality parameters obtained in this study, the temperature is possibly the most influential factor on sheatfish's gonad matura-
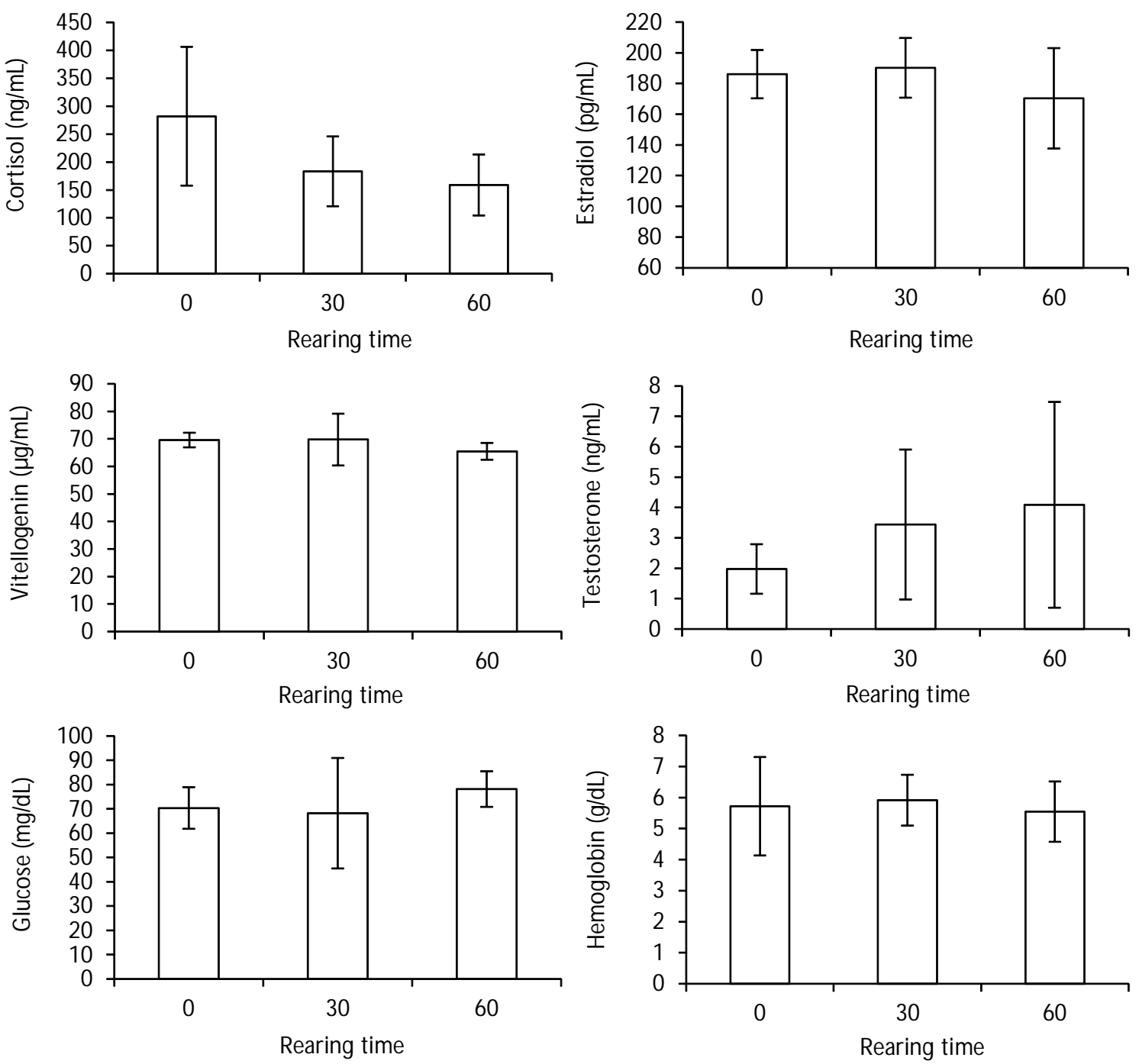

Figure 2. Physiological parameters of sheatfish 0 . miostoma reared in controlled tanks for 60 days. 
Table 3. Water quality parameters of sheatfish's controlled tanks during the study

\begin{tabular}{lc}
\hline \multicolumn{1}{c}{ Parameter } & Value \\
\hline Temperature $\left({ }^{\circ} \mathrm{C}\right)$ & $29.4-31.1($ Mean \pm SD: $29.9 \pm 0.6)$ \\
Dissolved oxygen $(\mathrm{mg} / \mathrm{L})$ & $5.32-7.22($ Mean \pm SD: $6.59 \pm 0.67)$ \\
$\mathrm{pH}$ & $6.6-7.8($ Mean \pm SD: $7.2 \pm 0.4)$ \\
Alkalinity $(\mathrm{mg} / \mathrm{L})$ & $50-76($ Mean \pm SD: $59.5 \pm 7.6)$ \\
Ammonia $(\mathrm{mg} / \mathrm{L})$ & $<0.001$ \\
\hline
\end{tabular}

tion. This statement is supported by previous results on other species in the same genus of Ompok, which documented the relationship between temperature and gonad maturation (Chakraborty et al., 2010; Malla $\&$ Banik, 2015). Therefore, it is important to maintain the temperature at the observed range in this study to increase the gonad development of sheatfish in controlled concrete tanks.

Based on the obtained results, it appears that the sheatfish could adapt and grow well in concrete tanks. It was supported by a $100 \%$ survival rate and good physiological conditions, e.g., cortisol and glucose. Jentoft et al. (2005) stated that cortisol and glucose are stress indicators that are often used to determine fish health status. Basal cortisol levels are usually $<10 \mathrm{ng} / \mathrm{mL}$ in wild teleosts. However, many species have greater values of cortisol for unstressed fish (Pankhurst, 2011). The magnitude of the corticosteroid response among species is considerably variable. Generally, peak values of cortisol vary between 30-300 $\mathrm{ng} / \mathrm{mL}$. However, it is also species dependent influenced by the length or severity of the stress (Barton, 2002). In our study, the sheatfish was likely experiencing a high-stress level from the first day but tended to decrease on the final day of rearing. However, we assume that sheatfish could maintain their physiological condition because no mortality occurred in this study. The normal blood glucose levels of fish are $40-90 \mathrm{mg} / \mathrm{dL}$ (Rahardjo et al., 2011). However, our results show that the blood glucose levels of sheatfish in this study were still in the normal range, which means the fish are not in stressed conditions.

In concrete tanks, fish can grow and mature even though the rates were prolonged ( $P>0.05)$, compared to well-domesticated fish species such as tilapia (Gustiano \& Arifin, 2010), Asian redtail catfish (Kusmini et al., 2019), and catfish (Gustiano et al., 2020a). The largest size of the fish obtained in the study reached $19.1 \mathrm{~cm}$. If compared to the size and level of gonad maturity of sample fish from the nature, which is around $15.6-19.1 \mathrm{~cm}$, it is estimated that the tested fish's gonad maturity level is between I and II. Jusmaldi et al. (2019) stated that the female sheatfish living in the floodplain swamp areas of Lake Semayang reached their gonad maturation at the size ranging from 17.9 to $19.8 \mathrm{~cm}$. Fully mature females (level-IV) were only found in November, December, January, and February (Jusmaldi et al., 2019). Based on the information, the gonad maturity of 0 . miostoma in its wild habitat is faster than that of observed in the present study. The fish reared in this experiment might undergo adaptation and dietary adjustments in the controlled environment, causing suppressed or halted gonad development. Relatively similar estradiol and vitellogenin levels from different observation times provided supporting evidence of such pressure. In contrast, there was a tendency for faster gonad development in males, which was reflected by an increase in testosterone levels as time progressed. According to Jusmaldi et al. (2018), sheatfish have a specific spatial distribution influenced by differences in habitat conditions, while its temporal distribution is affected by changes in climatic seasons. It is suggested that the fish distribution patterns have an immediate influence in ripening the fish gonads under natural habitat due to the relative mobility of the fish to find food. Therefore, further research needs to elaborate on the optimal nutrient requirements for growth and gonad development in concrete tanks.

Mature females of sheatfish were only found in November, December, and January, as previously discussed. The highest percentage of matured females (IV level) was found in December, while the lowest was found in February. Based on the ratio of matured females and males, it is strongly suggested that the sheatfish only has one spawning season per year. The spawning season begins during the rainy season in October, November, and December indicating the strong influence of seasonal weather on the gonad maturity of sheatfish. This knowledge means that a domestication program of sheatfish has to be channeled to disrupt these natural stimuli responsible for triggering the hormones for maturation. An alternative method that can be applied is hormonal implantation, which has been used to striped snakehead Channa striata (Gustiano et al., 2020b). Teletchea (2017) concluded that domestication is a long and 
endless process in which animals become more adapted to human interventions and captive conditions. Despite the complexity of the domestication process, aquaculture activities based on native fish species must be continuously carried out to maintain biodiversity and support food security.

\section{CONCLUSION}

This study successfully determined that the sheatfish are able to adapt, grow to the average size of $16.4 \mathrm{~cm}$, and develop their gonads to reach gonad maturity levels ranging between I and II in concrete tanks. The temperature could be one of the critical parameters in improving the gonad development of sheatfish. Further study is expected to accelerate the growth and gonad maturity level of reared fish by providing optimal feed formulation and implanted hormones to provide fish a signal for gonad maturation.

\section{ACKNOWLEDGEMENTS}

The authors would like to thank Anang Hari Kristanto, Fera Permata Putri, Sri Sundari, M. Sofyan, Bambang Priadi, Deni Irawan, and Sutarman for their technical assistance during the research. This research was funded by DIPA APBN 2020 (Contract number: SP DIPA-032.12.2.403829/2020) for Research Institute for Freshwater Aquaculture and Fisheries Extension (BRPBATPP).

\section{REFERENCES}

Arthi, T., Nagarajan, S., Vijayaraman, K., \& Sivakumar, A.A. (2013). Fecundity and sex-ratio of two freshwater fishes, Ompok bimaculatus and 0 . malabaricus (Bloch) of the River Amaravathy, Tamil Nadu, India. The Bioscan, 8(1), 159-163.

Balon, E.K. (2004). About the oldest domesticates among fishes. Journal of Fish Biology, 65, 1-27.

Bagenal, T.B. (1978). Methods for assessment of fish production in fresh water. IBP. Handbook (3). Oxford: Blackwell Scientific Publication, 253 pp.

Barton, B.A. (2002). Stress in fishes: A diversity of responses with particular reference to changes in circulating corticosteroids. Integrative and Comparative Biology, 42, 517-525.

Boyd, C.E. (2000). Water quality in ponds for aquaculture. Department of Fisheries and Allied Aquaculture. Alabama Agricultural Experiment Station. Alabama: Auburn University, 482 pp.

Chakraborty, B.K., Mirza, Z.A., \& Chakraborty, A. (2010). Reproductive cycle of the endangered
Pabda, Ompok pabda (Hamilton-Buchanan, 1822) in Bangladesh. Asian Fisheries Science, 23(3), 301-320.

De Silva, S.S. (1986). Reproductive biology of Oreochromis mossambicus population of man-made lake in Sri Lanka: A comparative study. Aquaculture Research, 17(1), 31-47.

Effendie, M.I. (1997). Biologi perikanan. Yogyakarta: Yayasan Pustaka Nusantara, 163 pp (in Indonesian).

Elvyra, R., Dedy, D.S., Ridwan, A., \& Zairin, J. (2010). Kajian aspek reproduksi ikan lais Ompok hypophthalmus di Sungai Kampar, Kecamatan Langgam, Kabupaten Pelalawan, Provinsi Riau. Jurnal Natur Indonesia, 12(2), 117-123 (in Indonesian).

Gustiano, R. \& Arifin. O.Z. (2010). Menjaring laba dari budi daya ikan nila BEST. Bogor: IPB Press, 81 pp (in Indonesian).

Gustiano, R., Prakoso, V.A., Iswanto, B., Radona, D., Kusmini, I.I., \& Ath-thar, M.H.F. (2020a). Biodiversitas, status, dan tren budidaya ikan lele. Bogor: IPB Press, 88 pp (in Indonesian).

Gustiano, R., Ath-thar, M.H.F., Kristanto, A.H., Prakoso, V.A., Kusmini, I.I., \& Saputra, A. (2020b). Controlling gonad maturation on snakehead (Channa striata, Bloch 1793) for eliminating impact of climate change. IOP Conference Series: Earth and Environmental Science, 521(1), 012028.

Handayani, T., Buchar, T., \& Anang, N. (2009). Aspek biologi ikan lais sheatfish (Siluridae) di Danau Batu dan Danau Tehang. Journal of Tropical Fisheries, 3(2), 35-46 (in Indonesian).

Herawati, T., Syaiful, M., Bangkit, I., Sahidin, A., Yustiati, A., \& Dhahiyat, Y. (2020a). Fish community structure before reservoir inundation in Cipanas, West Java. IOP Conference Series: Earth and Environmental Science, 535(1), 012059. IOP Publishing.

Herawati, T., Wahyudewantoro, G., Andriani, Y., Herawati, H., \& Siregar, N.M.Y. (2020b). Fish diversity in the downstream region of Cipanas River Indramayu, West Java Indonesia. Zoo Indonesia, 29(1), 29-38.

Jentoft, S., Aastveit, A.H., Torjesen, P.A., \& Andersen, $\varnothing$. (2005). Effects of stress on growth, cortisol and glucose levels in non-domesticated Eurasian perch (Perca fluviatilis) and domesticated rainbow trout (Oncorhynchus mykiss). Comparative Biochemistry and Physiology Part A: Molecular \& Integrative Physiology, 141(3), 353-358. 
Jusmaldi, Solihin, D.D., Affandi, R., Rahardjo, M.F., \& Gustiano, R. (2017). Gonad maturity and spawning type of silurid catfishes, Ompok miostoma (Vaillant, 1902) from Mahakam watershed, East Kalimantan. Jurnal Iktiologi Indonesia, 17(2), 201213 (in Indonesian).

Jusmaldi, J., Solihin, D.D., Affandi, R., Rahardjo, M.F., \& Gustiano, R. (2018). Sebaran dan kekayaan spesies ikan lais (famili Siluridae) di Sungai Mahakam Kalimantan Timur. Proceeding of Biology Education, 2(1), 18-25 (in Indonesian).

Jusmaldi, Solihin, D.D., Affandi, R., Rahardjo, M.F., \& Gustiano, R. (2019). Reproductive biology of silurid catfishes Ompok miostoma (Vaillant 1902) in Mahakam River East Kalimantan. Jurnal Iktiologi Indonesia, 19(1), 13-29 (in Indonesian).

Kusmini, I.I., Radona, D., Ath-thar, M.H.F., Putri, F.P., Kristanto, A.H., \& Gustiano, R. (2019). Phenotypic diversity in three generations of domesticated Asian redtail catfish, Hemibagrus nemurus (Valenciennes, 1840) in Indonesia. Aquaculture, Aquarium, Conservation \& Legislation, 12(1), 4250.

Legendre, M. \& Ecoutin, J.M. (1989). Suitability of brackish water tilapia species from the Ivory Coast for lagoon aquaculture. I-Reproduction. Aquatic Living Resources, 2(2), 71-79.

Longenecker, K., Langston, R., \& Franklin, E.C. (2020). Standard operating procedure for histology-based rapid reproductive analysis of tropical fishes. Report prepared by the University of Hawaii at Manoa (UHM) for Tetra Tech's Supplemental Technical Assistance to the USAID SEA Project and Walton Family Foundation. 92 pp.

Malla, S. \& Banik, S. (2015). Reproductive biology of an endangered catfish, Ompok bimaculatus (Bloch, 1794) in the lotic waterbodies of Tripura, NorthEast India. International Journal of Fisheries and Aquatic Studies, 2(4), 251-260.

Minggawati, I., Sukoso, Bijaksana, U., \& Hakim, L. (2015). Gonad maturity level of catfish Ompok hypopthalmus caught in a flooding swamp area of Rungan River Central Kalimantan related to water depth. Global Journal Fisheries Aquatic, 3(2), 205-210.

Muslim, M., Heltonika, B., Sahusilawane, H.A., Wardani, W.W., \& Rifai, R. (2020). Ikan lokal perairan tawar Indonesia yang prospektif dibudidayakan. Jawa Tengah: C.V. Pena Persada, 132 pp (in Indonesian).
Pankhurst, N.W. (2011). The endocrinology of stress in fish: An environmental perspective. General and Comparative Endocrinology, 170(2), 265-275.

Pratiwi, N.T., Adiwilaga, E.M., Basmi, J., Krisanti, M., $\&$ Hadijah, 0. (2007). Status limnologis Situ Cilala mengacu pada kondisi parameter fisika, kimia, dan biologi perairan. Jurnal Perikanan Universitas Gadjah Mada, 9(1), 82-94 (in Indonesian).

R Core Team. (2020). R: A language and environment for statistical computing. R Foundation for Statistical Computing, Vienna, Austria. URL https:// www.R-project.org/.

Rahardjo, M.F., Sjafei, D.S., Affandi, R., \& Sulistiono. (2011). Iktiologi. Bandung: Lubuk Agung, 396 pp (in Indonesian).

Sahli, H. (1909). Untersuchungen Methode, 5th ed. Lehrbuch d. klin, Leipzig, $846 \mathrm{p}$.

Sukadi, M.F., Kristanto, A.H., Nugroho, E., Komarudin, O., Widiyati, A., Gustiano, R., Djajasewaka, H., \& Kusmini, I.I. (2009). Candidates for local freshwater fish commodities: the potential for cultivation development in South Kalimantan. In A. Sudrajat, H. Supriyadi, \& A. Hanafi (Eds.), Prosiding Forum Inovasi Teknologi Akuakultur 2009. (p. 365373) (in Indonesian).

Sjafei, D.S., Simanjuntak, C.P.H., \& Rahardjo, M.F. (2008). Development of gonad maturity and spawning pattern of Ompok hypophtahlmus in floodplain of Kampar Kiri River, Riau. Jurnal Iktiologi Indonesia, 8(2), 93-99 (in Indonesian).

Teletchea, F. \& Fontaine, P. (2014). Levels of domestication in fish: Implications for the sustainable future of aquaculture. Fish and Fisheries, 15(2), 181-195.

Teletchea, F. (2017). Wildlife conservation: Is domestication a solution?. Global Exposition of Wildlife Management, Dr. Gbolagade Akeem Lameed (Ed.), In Tech, DOI:10.5772/65660. Available from: https:/ /www.intechopen.com/books/global-expositionwildlife-management/wildlife-conservationisdomestication-a-solution. Accessed 15 November 2020.

Wisnu, R.P., Karuniasa, M., \& Moersidik, S.S. (2021). The impact of fish feed on water quality in Lake Cilala, Bogor Regency, West Java. IOP Conference Series: Earth and Environmental Science,716(1), 012023. IOP Publishing.

Wolf, J.C. \& Smith, S.A. (1999). Comparative severity of experimentally induced mycobacteriosis in striped bass Morone saxatilis and hybrid tilapia Oreochromis spp. Diseases of Aquatic Organisms, 38, 191-200. 